\title{
PKM Pelatihan Media Modifikasi Pendidikan Jasmani Bagi Guru-Guru Pendidikan Jasmani Olahraga Dan Kesehatan SD Di Kecamatan Cina Kabupaten Bone
}

\author{
Muliadi $^{1}$, Sudirman ${ }^{2}$, Abd. Kadir. A. ${ }^{3}$ \\ ${ }^{1,2,3}$ Fakultas Ilmu Pendidikan, Universitas Negeri Makassar
}

\begin{abstract}
The purpose of PKM training in the modification of Physical Education media for the KKG PJOK SD in the Cina sub-district of Bone Regency is to make learning media / teaching aids as a way to increase teacher professionalism and overcome the problem of limited physical education facilities. Training on making physical modification media for Physical Education has 2 output targets. The first is targeting SD Penjas teachers in Cina sub-districts to be able to design / design modified Physical Education media from used materials / goods, with various types according to the teaching material. The second target is skilled teachers to make modified Physical Education media in elementary schools that are attractive, effective, and efficient in their use in learning PJOK in SD.The methods used in service activities are: 1) Lecture to deliver; Basic concepts of modification media, Modification Objectives, Utilization of Modified Media for Physical Education learning, as well as materials for Design Development and Types of Physical Education learning media in SD. 2) The demonstration is used with the hope that participants can practice how to design used materials / goods to make modified physical education media in elementary schools. To further optimize the implementation of the training, assistance is provided by the service team, namely designing and making attractive and effective modification media of Physical Education according to the teaching materials of PJOK in SD, 3) Questions and Answers, used to respond to various obstacles faced by teachers in designing / designing, making modification media Physical Education and 4) Practices / simulations or trials of using the Modified Physical Education media in SD. The participation of partners during the training shows a responsive and active attitude in asking questions and completing tasks given by the service team. The results achieved by partners are showing motivation, knowledge and understanding so that they are able to design / design and make modified Physical Education media from used goods. Although in general the teachers are still constrained by several things; not used to making interesting media, time is very limited because of the many main tasks and other tasks; Sports coach, Scout, and so on. However, through this training it can provide knowledge in designing modified Physical Education media and make and use it to help teachers and students in the learning process to improve the quality of PJOK learning in SD sub-district Cina, Bone district.
\end{abstract}

Keywords: Training, Modified Media, Physical Education

\section{PENDAHULUAN}

Pendidikan jasmani merupakan bagian integral dari sistem pendidikan secara keseluruhan. Pendidikan sebagai proses pembinaan manusia yang berlangsung seumur hidup mempunyai peranan yang sangat penting yaitu memberi kesempatan kepada siswa untuk terlibat langsung dalam aneka pengalaman belajar melalui aktivitas jasmani. Pendidikan jasmani merupakan proses pendidikan yang memanfaatkan aktivitas jasmani yang direncanakan secara sistematik, bertujuan untuk meningkatkan individu secara organik, neuromuscular, perceptual, kognitif, sosial dan emosional. (Depdiknas, 2006).
Jadi pendidikan jasmani merupakan media untuk mendorong pertumbuhan fisik, perkembangan psikis, keterampilan motorik, pengetahuan dan penalaran, dan penghayatan nilainilai serta pembiasaan pola hidup sehat untuk merangsang pertumbuhan dan perkembangan kualitas fisik dan psikis yang seimbang. Yang membedakan antara pendidikan jasmani dengan mata pelajaran lain adalah alat yang digunakan yaitu gerak insani atau manusia yang bergerak secara sadar.

Tujuan ideal program pendidikan jasmani bersifat menyeluruh, sebab mencakup bukan hanya aspek fisik tetapi juga aspek lainnya yang mencakup aspek intelektual, emosional, sosial dan 
moral dengan maksud kelak anak muda itu menjadi pemuda yang percaya diri, berdisiplin, sehat, bugar, dan hidup bahagia. Terkait dengan modifikasi media Penjas, Lutan, R. 2000:15) menyatakan bahwa "Modifikasi dalam mata pelajaran pendidikan jasmani diperlukan, dengan tujuan agar siswa memperoleh kepuasan dalam mengikuti pelajaran, meningkatkan kemungkinan keberhasilan dalam berpartisipasi dan dapat melakukan pola gerak secara benar". Pendekatan ini dimaksudkan agar materi dapat disajikan sesuai dengan tahapan perkembangan siswa, baik dari segi kognitif, afektif dan psikomotor sehingga tujuan dari pembelajaran dapat tercapai.

Modifikasi digunakan sebagai salah satu alternatif pendekatan dalam pembelajaran pendidikan jasmani yang dilakukan dengan berbagai pertimbangan. Seperti yang dikemukakan oleh Soepartono (2000), bahwa alasan utama perlunya modifikasi adalah: 1). Anak bukanlah orang dewasa dalam bentuk kecil, kematangan fisik dan mental anak belum selengkap orang dewasa, 2). Pendekatan pembelajaran pendidikan jasmani selama ini kurang efektif, hanya bersifat literal dan monoton, 3). Sarana dan prasarana pembelajaran pendidikan jasmani yang ada sekarang hamper semuanya di desain untuk orang dewasa.

Sedangkan Aussie (Bahagia, Y., 2010) mengembangkan modifikasi media penjas dengan pertimbangan 1). Anak-anak belum memiliki kematangan fisik dan emosional seperti orang dewasa, 2). Berolahraga dengan peralatan dan peraturan yang dimodifikasi akan mengurangi cedera pada anak. 3). Olahraga yang dimodifikasi akan mampu untuk mengembangkan keterampilan anak lebih cepat dibandingkan dengan peralatan yang standard untuk orang dewasa, 4). Olahraga yang dimodifikasi menumbuhkan kegembiraan dan kesenangan pada anak-anak dalam situasi kompetitif. Jadi Pendidikan Jasmani memberikan kesempatan pada siswa untuk terlibat langsung dalam aneka pengalaman belajar meluli aktivitas jasmani, bermain, dan berolahraga yang dilakukan secara sistematis, terarah dan terencana. Pembekalan pengalaman belajar itu diarahkan untuk membina, sekaligus membentuk gaya hidup sehat dan aktif sepanjang hayat.

Dalam proses pembelajaran pendidikan jasmani guru harus dapat mengajarkan berbagai keterampilan gerak dasar, teknik dan strategi permainan / olahraga, internalisasi nilai-nilai (sportifitas, jujur kerja sama, dan lain-lain) dari pembiasaan pola hidup sehat. Pelaksanaannya bukan melalui pengajaran konvensional di dalam kelas yang bersifat kajian teoritis, namun melibatkan unsur fisik mental, intelektual, emosional dan social. Aktivitas yang diberikan dalam pelajaran harus mendapatkan sentuhan dikdaktik-metodik, sehingga aktivitas yang dilakukan dapat mencapai tujuan pengajaran. Melalui pendidikan jasmani diharapkan siswa dapat memperoleh berbagai pengalaman untuk mengungkapkan kesan pribadi yang menyenangkan, kreatif, inovatif, terampil, meningkatkan dan memelihara kesegaran jasmani serta pemahaman terhadap gerak manusia. Untuk menumbuhkan dan meningkatkan sikap aktif, kreatif, kompetitif dari siswa sebenarnya tidaklah mudah. Karena kenyataannya guru dianggap sebagai sumber belajar yang paling utama dan paling benar, dan memposisikan siswa sebagai pendengar ceramah dari guru. Akibatnya proses belajar mengajar cenderung membosankan dan menjadikan siswa kurang termotivasi untuk belajar. Dan sikap anak didik yang pasif ternyata tidak hanya terjadi pada mata pelajaran tertentu saja tetapi hampir semua mata pelajaran termasuk pendidikan jasmani olahraga dan kesehatan. Seyogianya banyak cara yang dapat dilakukan untuk meningkatkan hasil belajar pendidikan jasmani di SD. Salah satunya adalah dengan menerapkan pembelajaran melalui bantuan media. Media pembelajaran merupakan salah satu strategi mengajar yang diharapkan dapat meningkatkan hasil belajar siswa, karena dengan menggunakan media pembelajaran penyampaian materi pembelajaran dapat diseragamkan dan proses belajar siswa lebih menarik (Soekatamsi, 2000). Keberhasilan proses kegiatan belajar mengajar pada pembelajaran pendidikan jasmani dapat diukur dari keberhasilan siswa yang mengikuti 
kegiatan tersebut. Keberhasilan itu dapat dilihat dari tingkat pemahaman, penguasaan materi dan hasil belajar, maka semakin tinggi pula tingkat keberhasilan pembelajaran. Media pembelajaran adalah salah satu faktor penting dalam proses pembelajaran dalam pendidikan jasmani. Dengan adanya media-media pembelajaran yang disesuaikan dengan materi pembelajaran serta karakteristik peserta didik tentu akan sangat membantu guru dalam mencapai kompetensi yang diinginkan dari materi pembelajaran yang berlangsung. Untuk itu penggunaan media dalam suatu proses belajar mengajar sangat diperlukan, karena media mempunyai kelebihan, secara teknis mampu membantu proses belajar mengajar yang baik juga mampu meningkatkan gerak dasar dan keterampilan gerak peserta didik, (Saputra, 2001).

Dari uraian yang dikemukakan di atas, kenyataan di sekolah-sekolah termasuk di sekolah dasar di kabupaten Bone pada umumnya masih banyak guru pendidikan jasmani yang masih terbatas dalam melaksanakan pembelajaran karena berbagai macam keterbatasan, keterbatasan tersebut antara lain dalam menyediakan alat atau media pembelajaran Penjas dalam kegiatan pembelajaran.

Berdasarkan observasi dan wawancara penulis dengan beberapa guru Penjas SD di Kecamatan Cina Kabupaten Bone terungkap bahwa masih ditemukan sebagian besar guru pendidikan jasmani yang belum memiliki kemampuan dan keterampilan dalam pemanfaatan media pembelajaran. Para guru beranggapan bahwa media pembelajaran yang digunakan harus standard dan ketersediaannya di sekolah masih sangat kurang. Sehingga pengabdi berpendapat bahwa guru-guru PJOK di wilayah Kecamatan Cina Kabupaten Bone belum mampu dan belum terampil dalam pemanfaatan media pembelajaran yang dapat dimodifikasi sera dapat memberdayakan barangbarang bekas seperti: kardus, ban sepeda bekas, bilah bamboo, bola plastic berisi pasir untuk tolak peluru, kaleng susu bola tenis bekas, serta bahanbahan lainnya yang dapat dimodifikasi sesuai dengan kebutuhan materi pembelajaran Penjas di sekolah dasar.
Modifikasi merupakan salah satu upaya yang dapat dilakukan oleh para guru PJOK agar proses pembelajaran dapat terlaksana secara efisien dan efektif. Tidak sedikit guru penjas yang terjebak dalam ketergantungan penyajian materi pembelajaran penjas kepada hal-hal yang sifatnya prinsip dan standard serta harus sesuai dengan kurikulum yang sudah ditentukan. Minimnya fasilitas dan perlengkapan pendidikan jasmani yang dimiliki sekolah-sekolah, menuntut guru penjas untuk lebih kreatif dalam memberdayakan dan mengoptimalkan penggunaan fasilitas dan perlengkapan yang ada sesuai dengan kondisi siswa dan sekolahnya. Tidak sedikit siswa yang merasa gagal atau kurang menyukai materi pembelajaran yang disampaikan oleh gurunya karena kemampuan guru dalam menyampaikan materi yang diberikan, baik dalam penggunaan fasilitas dan perlengkapan yang digunakan, dalam penyajian materi, dalam mengoptimalkan lingkungan pembelajaran maupun dalam mengevaluasi hasil pembelajaran. Jadi esensi modifikasi media pembelajaran penjas adalah menganalisis sekaligus mengembangkan materi pelajaran dalam bentuk aktivitas belajar yang potensial sehingga dapat memperlancar siswa dalam belajarnya. Dengan memanfaatkan barang bekas sebagai media pembelajaran pendidikan jasmani di sekolah dasar, maka secara langsung akan membuat efisiensi pembiayaan dalam pengadaan peralatan sekolah. Saat ini sarana dan prasarana media pembelajaran penjas yang tersedia semua dalam bentuk yang standar dan tidak cocok dengan usia siswa sekolah dasar, kalaupun ada harganya juga sangat mahal dan suit untuk mendapatkannya. Oleh sebab itu, perlu kiranya para guru penjas SD dirangsang untuk mau dan mampu memodifikasi media pembelajaran Pendidikan Jasmani sekolah dasar dengan memanfaatkan barang bekas.

\section{METODE PENGABDIAN}

Berdasarkan permasalahan yang telah dikemukakan, maka dalam kegiatan ini, metode pendekatan yang dilaksanakan bagi realisasi program ini adalah Pelatihan dan Pendampingan. 


\section{Tahap Pelaksanaan Kegiatan}

Pada tahap pelaksanaan kegiatan PKM pelatihan Media Modifikasi Pendidikan Jasmani SD kecamatan Cina ini dilaksanakan sebanyak empat kali pertemuan baik secara virtual (tatap maya) maupun tatap muka langsung dengan tetap menjaga Protokol kesehatan (mencuci tangan, memakai masker, dan menjaga jarak) dengan Mitra, yaitu sebagai berikut:

Pada tahap pertama pelaksanaan kegiatan PKM Media Modifikasi Pendidikan Jasmani SD kecamatan Cina dilaksanakan pada Sabtu 27 Juni 2020, di awali dengan acara pembukaan terpadu dari 6 Tim Pengabdi yang berlokasi di Kabupaten Bone, yaitu 5 Tim Pengabdi yang lokasinya di dalam Kota Watampone dan 1 Lokasi di luar kota yakni KKGPJOK Kecamatan Cina Kabupaten Bone dan acara pembukaan PKM terpadu ini dilaksanakan secara Virtual (Aplikasi Zoom) karena pandemi Corona Covid 19 yang dihadiri oleh, Dekan Fakultas Ilmu Pendidikan UNM Dr. Abdul Zaman, S. Pd, M. Si. Kons. Ketua LP2M UNM Prof. Dr.Ir. H. Bakhrani A. Rauf, M.T., Kepala Pusat Pengabdian Masyarakat dan Koordinator PPM Terpadu, LP2M UNM Dr.Syamsidah M. Pd., Kepala Dinas Pendidikan dan Kebudayaan Kabupaten Bone diwakili oleh Drs. Nursalam, M. Pd, Sekretris Dinas Pendidikan dan Kebudayaan Kabupaten Bone, Ketua Program Studi PGSD FIP UNM Muhammad Irfan S. Pd., M. Pd, Ketua UPP PGSD Bone Drs. Abd. Hafid, S. Pd, M. Pd, Kepala UPT SD yang ditempati pengabdian, Ketua dan Sekretaris KKG PJOK kecamatan Cina kabupaten Bone dan Guru-guru SD peserta pelatihan serta Tim pengabdi yang terdiri dari dosen dan beberapa mahasiswa. Ketua LP2M dalam sambutannya, disebutkan bahwa program kemitraan masyarakat ini merupakan salah satu tugas Tri Dharma Perguruan Tinggi, sehingga tanggungjawab terhadap pelaksanaan pengabdian merupakan tanggung jawab setiap dosen, bukan institusi semata. Lebih jauh disampaikan bahwa program ini merupakan program yang sangat penting dalam upaya mensosialisasikan IPTEKS kepada masyarakat (guru-guru SD) yang selalu berkembang setiap saat, dan sarat akan pengetahuan-pengetahun terbarukan. Disamping itu yang tidak kalah pentingnya bahwa program ini adalah jawaban dari masalah-masalah yang dihadapi oleh guru-guru tidak terkecuali yang ada di kabupaten Bone di dalam proses pembelajarannya. Oleh sebab itu, kami sangat menyambut baik kegiatan ini, dan merupakan kebutuhan bagi guru-guru yang ada di daerah Kabupaten Bone untuk menjawab permasalahan-permasalahan yang dihadapi di sekolah dasar. Sementara sambutan dari Dekan Fakultas Ilmu Pendidikan Universitas Negeri Makassar menyatakan bahwa kegiatan PKM yang dilaksanakan oleh para Dosen FIP ini adalah kegiatan Tridarma oleh dosen yang diharapkan membantu para mitra kerja yaitu Guru-guru khususnya yang ada di kabupaten Bone. Lanjut disampaikan bahwa dari 6 lokasi mitra yang diadakan oleh dosen pengabdi PNBP anggaran 2020 tentu beruntung dan bersyukur teman guruguru SD akan mendapatkan pelatihan atau pendampingan tentang berbagai keterampilan guru dalam melaksanakan proses kegiatan pembelajaran di SD, dan sepanjang sejarah pelaksanaan PKM yang dilaksanakan oleh UNM selama ini baru kali ini pelatihan diadakan dalam masa pandemi Covid 19 ini yang dilakukan secara online atau tidak seperti biasanya yaitu langsung secara tatap muka. Namun Dekan FIP UNM tetap optimis dapat terlaksana dengan baik. Pada akhir sambutannya menginstruksikan agar para guru mitra sebagai peserta pelatihan dapat mengikuti kegiatan ini dengan baik sampai akhir dan meminta kepada Tim pengabdi agar dalam kegiatan PKM untuk hari-hari ke depan dapat dilakukan di tempat lain (kecamatan lain dalam wilayah kabupaten Bone) dan semoga kegiatan PKM dilaksanakan dengan rasa tanggungjawab oleh Pengabdi dan Guru-guru peserta pelatihan sehingga tujuan tercapai dan bermanfaat bagi almamater, masyarakat bangsa dan Negara. Selanjutnya setelah kata sambutan sekaligus bapak Dekan FIP UNM membuka secara resmi kegiatan PKM.

Setelah acara pembukaan terpadu, dilanjutkan dengan pemaparan materi sesuai dengan lokasi masing-masing pengabdi. 
PKM Pelatihan Media Modifikasi Pendidikan Jasmani bagi Guru-guru PJOK SD di Kecamatan Cina Kabupaten Bone yaitu kegiatan pelaksanaan workshop hari pertama disajikan materi tentang Konsep Media Modifikasi, Pemanfaatan Media Modifikasi pembelajaran Penjas, serta materi pengembangan desain dan jenis-jenis media pembelajaran Penjas di sekolah dasar. Dimaksudkan untuk memberikan pelatihan dan juga pengetahuan secara menyeluruh tentang peranan/pentingnya media Modifikasi dalam pembelajaran Penjas bagi seorang guru untuk dapat memotivasi siswa dalam belajar. Disamping hal tersebut pelaksanaan workshop ini juga memberikan ruang yang cukup luas bagi guru untuk menyampaikan segala permasalahan mereka terkait tentang rendahnya antusias guru merancang media penjas yang sederhana dan efektif pemanfaatannya di SD mengingat media sangat terbatas dan memerlukan biaya yang banyak. Secara garis besar pelaksanaan workshop dilakukan dengan metode ceramah disertai Pawer Point, tanya jawab, dan Vidio pembelajaran Penjas menggunakan media modivikasi. Sedangkan untuk demonstrasi dan diskusi untuk dapat mencari sumber-sumber masalah dari tiap-tiap sekolah peserta pelatihan khususnya media Penjas di SD sangat terbatas sebab kegiatan ini dilaksanakan secara Virtual (Zoom). Namun waktu yang terbatas tetapi kami dari Tim pengabdi tetap berusaha mengatur waktu sedemikian rupa sehingga masalah yang dihadapi guru Penjas di kecamatan Cina dapat diungkapkan dalam pertemuan workshop ini. Setelah mengetahui permasalahan-permasalahan yang dihadapi oleh masing-masing guru PJOK di sekolahnya masing-masing, maka pihak Tim penyaji menyusun strategi dan langkah-langkah strategis dalam menangani permasalahan yang ada. Beberapa tahapan kegiatan tersebut adalah:

1. Pemaparan materi workshop tentang: a) Konsep konsep media modifikasi Penjas di SD, b) Tujuan media modifikasi Pembelajaran Penjas di SD c) Pemanfaatan media modifikasi Pembelajaran Penjas di SD, d) Pengembangan Desain dan jenis-jenis media modifikasi pembelajaran Penjas di SD.
2. Pendampingan pembuatan media modifikasi Pendidikan Jasmani olahraga Kesehatan di SD.

3. Simulasi mengujicobakan cara pemanfaatan media modifikasi pembelajaran Penjas di SD.

\section{Tahapan Pertama Pemaparan Materi Workshop (Tatap maya/Virtual)}

Pada tahapan pelaksanaan kegiatan PKM ini yaitu pelaksanaan workshop secara virtual yang disampaikan oleh Tim Pengabdi pada intinya tahapan kegiatan ini pemateri menyampaikan secara garis besar empat masalah pokok yaitu; 1) Konsep media modifikasi Penjas di SD, 2) Tujuan media modifikasi Pembelajaran Penjas di SD 3) Pemanfaatan media modifikasi Pembelajaran Penjas di SD, dan 4) Pengembangan Desain dan jenis-jenis media modifikasi pembelajaran Penjas di SD. Pemateri memberikan kesempatan bagi semua guru untuk menyampaikan pertanyaan maupun kendala yang dihadapi oleh guru/peserta tentang masalah media modifikasi penjas yang dihadapi sehari-hari di sekolahnya masing-masing. Dalam kegiatan tanya jawab, banyak dijumpai permasalahan yang muncul pada tahapan ini, Sesi pertama terdapat beberapa orang dari peserta bertanya tentang: 1) bagaimana cara atau langkah guru dalam merancang media modifikasi yang menarik bagi siswa. 2) menanyakan media modifikasi Atletik tolak peluru dalam pembelajaran penjas di SD, 3) bagaimana memodifikasi media permainan dalam pembelajaran Penjas di SD, 4) apa saja hal penting yang harus diperhatikan sebelum merancang media modifikasi pembelajaran Penjas di SD dan 5) bahkan ada yang terbuka menyampaikan pemahaman guru yang belum begitu mengenal tentang istilah-istilah media modifikasi dalam suatu pembelajaran Penjas di SD.

Pertanyaan-pertanyaan tersebut dijawab oleh penyaji, dimana sebelum dijawab diberikan kesempatan kepada peserta workshop untuk menanggapi pertanyan tersebut. Kemudian selanjutnya diberikan penjelasan, dengan contohcontoh Media Pawer Point sesuai masalah yang dipertanyakan/dikemukakan peserta. Akhirnya setelah mendapatkan penjelasan dan contoh dengan 
jelas, maka para peserta merasa mengerti dengan jawaban yang diberikan oleh narasumber.

Pada sesi kedua, terdapat juga beberapa pertanyaan dari peserta menanyakan: 1) Bagaimana bahan/alat yang dibuat media modifikasi dalam pembelajaran senam di SD, 2) Dalam mendesain jenis-jenis media modifikasi Penjas pada materi kebugaran jasmani di SD, 3) Salah seorang peserta berbagi pengalaman terkait kesulitan dalam menentukan media modifikasi permainan bola kecil kasti di SD. Pertanyaanpertanyaan yang ada disesi 2 ini dijawab oleh penyaji/narasumber dengan memberikan penjelasan hal-hal yang berkaitan dengan media modifikasi senam sesuai kurikulum yang berlaku yaitu K.13 antara lain senam dasar, senam lantai, dan senam irama, ini semua dapat dimodifikasi alat peraga/media misalnya matras busa yang mahal di toko olahraga dapat dimodifikasi dengan membuat kasur dari jerami, sabut kelapa, kain atau bahan lainnya dari barang-barang bekas untuk kasur pengganti matras. Senam irama dapat dibuat media seperti tongkat, kertas, dan lain yang merupakan barang bekas dan dimanfaatkan secara sederhana tetapi efektif pemanfaatannya pada pembelajaran Penjas, kemudian menunjukkan beberapa contoh, sehingga peserta menjadi lebih mengerti tentang media modifikasi khususnya pada pembelajaran senam di SD. Dan selanjutnya mengenai pertanyaan tentang media modifikasi permainan bola kasti, Pertanyaan ini juga dijawab yaitu bawa untuk permainan bola kasti guru dapat memanfaatkan bola Tennes bekas dan kayu pemukul dengan sederhana tanpa harus beli bola dan pemukul yang permanen dan mahal.

Sesi ke tiga, sesi ini, peserta pelatihan diberikan kesempatan untuk bertanya dan menyampaikan hal-hal yang belum dipahami dan bertukar pengalaman terkait kendala-kendala yang pernah dialami dalam proses pembelajaran PJOK di SD kecamatan Cina kabupaten Bone. Pada sesi ini peserta tanpak tidak ada yang bertanya, tetapi hanya ada beberapa orang yang ingin mempetegas/memperjelas yang mereka pahami tentang Media modifikasi Penjas. Ini pertanda pula bahwa peserta semakin termotivasi untuk memahami materi yang diberikan oleh Tim Pengabdi. Akhirnya pada pelaksanaan kegiatan pertama pelatihan ini berakhir pada Jam 16.00 WITA.

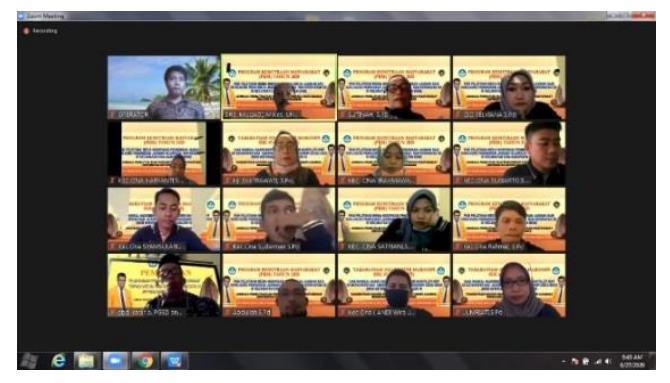

Gambar 2. Pemaparan Materi Workshop (Tatap maya/Virtual)

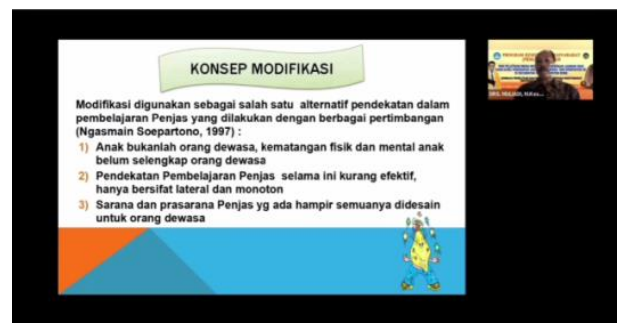

Gambar 3. Pemaparan Materi Workshop/ Power Point (Tatap maya/Virtual)

\section{Tahap kedua Pendampingan}

pembuatan media modifikasi Pendidikan Jasmani olahraga Kesehatan di SD (dilakukan tatap muka langsung dengan mematuhi protokol kesehatan) dengan meminta izin pada kepala kelurahan Tanete Harapan.

Pada tahapan kedua kegiatan PKM dilaksanakan yaitu, Sabtu 04 Juli 2020 bertempat di lapangan sepak bola Cina kecamatan Cina kabupaten Bone. Kegiatan pendampingan ini pelaksanaannya sama dengan pertemuan Pertama, dimulai pada Jam 08.00 sampai Jam 15.00 WITA, kegiatan pada tahap ini peserta pelatihan diberi penugasan untuk merancang media modifikasi sesuai ruang lingkup materi Penjas di SD pada K.13 yaitu: Gerak dasar Lokomotor dan Non Lokomotor, Manipulatif, Unsur kesegaran jasmani, Atletik, Senam, Permainan, Renang, bela diri serta kesehatan dan Rekreasi.

Tahap pendampingan pembuatan media modifikasi pembelajaran Penjas di SD oleh guru/peserta terbagi dalam 5 kelompok, setiap kelompok terdiri dari tiga orang. Topik atau tugas membuat media modifikasi Penjas di SD 
diserahkan kepada masing-masing kelompok merancang bahan atau barang bekas untuk dibuat media antara lain; ban sepeda bekas, botol plastik Aqua, Kardus indomi, bola tenis bekas, kain perca (kain sisa), bola plastik, sabut kelapa, jerami, bambu runcing, selang bekas (hula hoop), karet gelang (lompat), keranjang plastik, kertas metalik, pasir, piring plastik, tali rapiah, kapur bubuk dan lain yang mudah didapat di lingkungan masingmasing peserta. Sedangkan alat yang dipakai untuk membuat media modifikasi adalah alat yang sederhana antara lain; Gunting, lem Fox, Doble tape (isolasi), cat (warna warni), gergaji, pisau, dan lainnya.

Pada tahap pendampingan pembuatan media modifikasi penjas masing-masing kelompok membuat dengan diberikan masukan-masukan seperlunya oleh tim pengabdi. Proses pembuatan media modifikasi sesuai materi ajar Penjaskes berlangsung selama dua minggu oleh karena masing-masing guru masih harus mengerjakan tugas sebagai guru seperti sedia kala seperti tugas mengajar dan tugas administrasi guru lainnya.

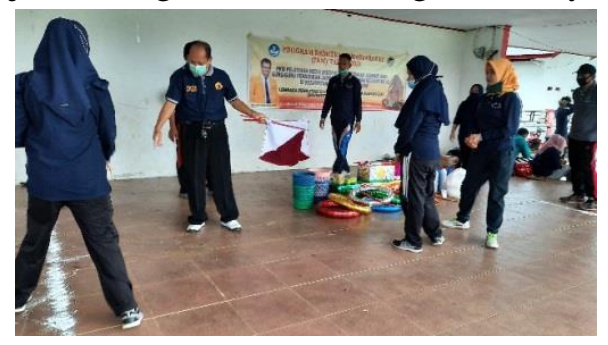

Gambar 4 Pendampingan Kegiatan PKM Media Modifikasi Penjas di SD (Tatap Muka Langsung menerapkan Protokol Kesehatan dan Izin Pemerintah Setempat)

\section{Tahap ketiga kegiatan Simulasi}

Mengujicobakan cara pemanfaatan media modifikasi pembelajaran Penjas di SD. Pada tahapan simulasi ujicoba dilaksanakan yaitu, Sabtu 18 Juli 2020 bertempat di lapangan sepak bola Cina kecamatan Cina kabupaten Bone, dimulai pada Jam 08.00 sampai Jam 12.00 WITA dilakukan secara tatap muka langsung dengan syarat tetap mematuhi protokol kesehatan, dengan meminta izin pada kepala kelurahan Tanete Harapan. Sebelum kegiatan dimulai Tim pengabdi mengingatkan kepada peserta pelatihan untuk mencuci tangan, memakai masker, dan menjaga jarak. Kemudian selanjutnya kegiatan simulasi ujicoba pemanfaatan media modifikasi Penjas di SD dilakukan dengan tiga tahapan kegiatan yaitu: a) Tahap Kegiatan Awal/pemanasan, b) Tahap kegiatan Inti, dan c) Tahap kegiatan Penutup.

a. Kegiatan Awal/Pemanasan.

Peserta berbaris tiga bersap dengan menjaga jarak kurang lebih satu setengah meter sampai dua meter lalu diberikan arahan oleh ketua pengabdi sesuai tujuan pelatihan yang dicapai. Selanjutnya peserta bersama pengabdi melakukan gerakan pemanasan, mulai lari di tempat, gerakan kepala/leher, lengan, badan, dan tungkai secukupnya (7 sampai 10 menit).

\section{b. Kegiatan Inti}

(Simulasi Ujicoba pemanfaatan Media modifikasi Penjas) 10 sampai 15 menit satu kelompok

1) Kelompok A, Gerak dasar Lokomotor, non lokomotor dan manipulatif Kelompok ini memanfaatkan media modifikasi kardus indomi dengan materi jalan, lari, lompat dan loncat melewati rintangan kardus tersebut.

2) Kelompok B, simulasi melakukan berbagai unsur kesegaran jasmani yaitu unsur kekuatan, kecepatan, kelincahan, kelentukan, daya tahan, daya ledak, keseimbangan dengan memanfaatkan ban sepeda bekas, botol plastik Aqua, bola tenis bekas, kapur buuk (garis)

3) Kelompok C, simulasi materi Atletik dengan memanfaatkan media modifikasi bola plastik diisi pasir dijadikan peluru untuk tolak peluru, kayu yang ringan berbentuk selinder digunakan tongkat estafet lari sambung, lompat jangkit dengan media ban bekas dan kardus indomi.

4) Kelompok D, simulasi senam irama dengan media modifikasi bendera kecil dari potongan kain yang dibuat bendera dengan warna warni, Hula hoop terbuat dari selang bekas.

5) Kelompok E, simulasi materi permainan bola kecil dengan media modifikasi bola tenis bekas yaitu melempar dan menangkap bola pada berbagai teknik dasar (bola jauh melambung tinggi, datar dan datar/ menggelinding.

Kegiatan simulasi oleh masing-masing kelompok mensimulasikan pemanfaatan media modifikasi pembelajaran Penjas SD di depan tim 
Pengabdi dan semua guru-guru peserta pelatihan. Jadi setiap peserta mempunyai media modifikasi, sekalipun tugas ini dikerjakan secara berkelompok agar dapat saling kerjasama untuk saling bantu menyelesaikan tugas yang diberikan oleh Tim Pengabdi. Dalam kegiatan ini banyak sekali diskusi yang terjadi di antara guru, dan di akhir kegiatan diberikan masukan-masukan oleh tim Pengabdi.

\section{c. Kegiatan Penutup (10 sampai 15 menit)}

Pada kegiatan penutup simulasi ujicoba pemanfaatan media modifikasi pembelajaran Penjas di SD diberikan kesempatan kepada peserta untuk merfleksi hal yang kurang pada saat simulasi dan juga pengabdi memberikan motivasi kepada peserta untuk lebih kreatif, inovatif merancang media pembelajaran Penjas yang fektif dan efesien pemanfaatannya.

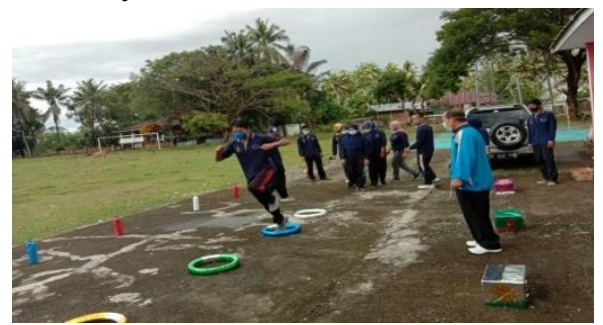

Gambar 5 Simulasi Uji Coba Pemanfaatan Media Modifikasi Penjas di SD Materi Jalan, Lari, dan Lompat (Tatap Muka

Langsung menerapkan Protokol Kesehatan dan Izin Pemerintah Setempat)

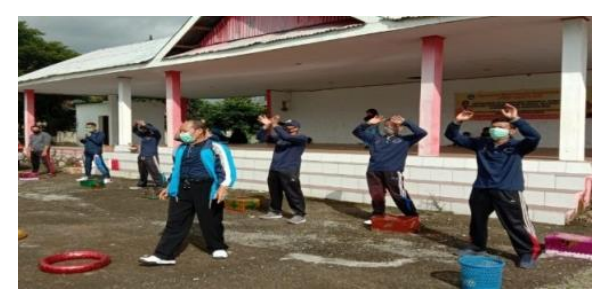

Gambar 6 Simulasi Uji Coba Pemanfaatan Media Modifikasi Penjas di SD Oleh Materi Melempar danMenangkap Bola kecil (Tatap Muka Langsung Menerapkan Protokol Kesehatan dan Izin Pemerintah Setempat)

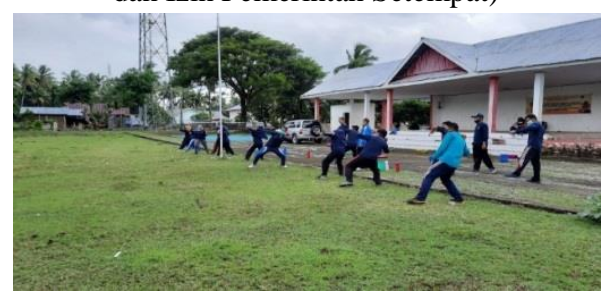

Gambar 7 Simulasi Uji Coba Pemanfaatan Media Modifikasi Penjas di SD Oleh Materi Melempar dan Menangkap Bola kecil (Tatap Muka Langsung Menerapkan Protokol Kesehatan dan Izin Pemerintah Setempat)

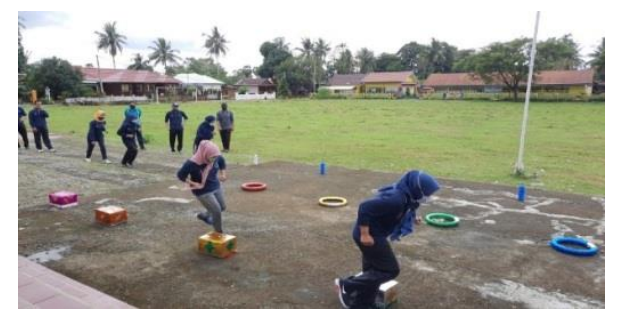

Gambar 8 Simulasi Uji Coba Pemanfaatan Media Modifikasi Penjas di SD Materi Latihan Kebugaran Jasmani (Tatap Muka Langsung menerapkan Protokol Kesehatan dan Izin Pemerintah Setempat)

\section{Tahap Akhir Kegiatan}

Pada tahapan akhir kegiatan PKM ini setelah dilaksanakan simulasi ujicoba pemanfaatan media modifikasi penjas di SD oleh peserta pelatihan, maka kegiatan selanjutnya adalah evaluasi yang merupakan kegiatan yang sangat penting dilakukan oleh Tim pengabdi dalam pelatihan ini.

Tujuan dari kegiatan ini adalah sebagai bentuk akumulasi dari tahapan kegiatan sebelumnya. Pada intinya tujuan dari PKM pelatihan pembuatan media modifikasi ini adalah untuk dapat membantu guru dalam pembuatan media modifikasi pembelajaran Penjas di SD kecamatan Cina Kabupaten Bone. Tahap Evaluasi ini dilaksanakan pada hari Sabtu, 25 Juli 2020 dimulai pada Jam 08.00 sampai Jam 12.00 WITA dilakukan secara tatap muka langsung dengan syarat tetap mematuhi protokol kesehatan, dengan meminta izin kepada kepala kelurahan Tanete Harapan kecamatan Cina. Sebelum kegiatan dimulai Tim pengabdi mengingatkan kepada peserta pelatihan untuk mencuci tangan, memakai masker, dan menjaga jarak.

Pada tahap akhir kegiatan ini, Tim pengabdi juga melakukan wawancara kepada beberapa peserta untuk mendapatkan informasi terkait keefektifan pelaksanaan PKM, kebermanfaatan dan menilai pemahaman peserta setelah diberikan pelatihan tersebut. Dari hasil wawancara singkat tersebut pada saat penutupan acara, peserta sebagian besar meyatakan bahwa pelatihan ini efektif, sangat bermanfaat dan mereka telah paham apa yang diberikan, baik itu mengenai materi tentang media secara umum, media modifikasi tentang tujuan dan manfaat terhadap pembelajaran Penjas di SD, maupun merancang dan membuat 
berbagai jenis media modifikasi penjas, dan mereka menyarankan agar kegiatan pelatihan seperti ini rutin untuk dilakukan agar kami bisa mengupdate pengetahuan kami secara berkesinambungan. Peserta hingga akhir pertemuan masih tetap berjumlah 15 orang, sehingga dapat kami simpulkan bahwa peserta sangat tertarik dan sangat beresemangat dalam mengikuti PKM pelatihan media modifikasi penjas di SD bagi guruguru Pendidikan Jasmani Olahraga dan Kesehatan (PJOK) kecamatan Cina kabupaten Bone.

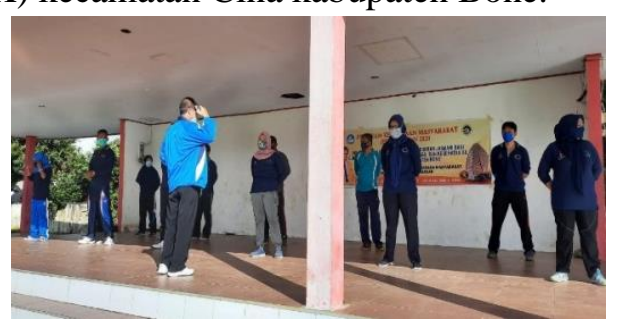

Gambar 9 Kegiatan Akhir (Evaluasi) Peserta PKM (Tatap Muka Langsung menerapkan Protokol Kesehatan dan Izin Pemerintah Setempat)

\section{PELAKSANAAN DAN HASIL KEGIATAN}

Secara umum, hasil pelaksanaan Program Kemitraan Masyarakat (PKM) ini adalah cukup baik dan responsif, artinya terdapat pemahaman para guru tentang profesinya, terutama dalam hal pemahaman, perancangan, pembuatan dan pemanfaatan media modifikasi pembelajaran Penjas SD. Para guru-guru PJOK SD kecamatan Cina kabupaten Bone sangat tertarik untuk meningkatkan profesinya. Pernyataan ini didukung oleh antusiasnya para guru dalam mengikuti dan mengajukan pertanyaan selama pelaksanaan kegiatan pengabdian pada masyarakat. Berkaitan dengan hal tersebut, para guru mempunyai kehendak untuk mendesain dan membuat media modifikasi Penjas yang menarik dan efesien dalam rangka untuk meningkatkan kualitas pembelajaran PJOK di SD. Di samping itu, para guru sudah dapat memahami dan sadar pentingnya media modifikasi dalam pembelajaran bagi siswa.

Pada awal dilaksanakannya kegiatan PKM ini, setelah diadakannya kesepakatan kerjasama antara pihak tim pengabdian dengan mitra yaitu KKG Pendidikan Jasmani Olahraga Kesehatan (PJOK) bagi guru-guru SD kecamatan Cina kabupaten Bone, bahwa berdasarkan kondisi di lapangan, dijumpai beragam permasalahan yang dialami oleh masing-masing guru (mitra) kaitannya dengan kegiatan proses pembelajaran PJOK SD kecamatan Cina, sehingga pemilihan masalah yang sangat mendesak dan perlu penanganan yang serius karena menyangkut masalah biaya pengadaan media PJOK sementara sekolah tidak menganggarkan maka, PKM Pelatihan pembuatan media modifikasi pembelajaran Penjas adalah salah satu kegiatan yang penting dilakukan dan sangat bermanfaat bagi siswa dan guru. Hasil-hasil kegiatan PKM ini dapat dijabarkan dalam pembahasan sebagai berikut:

a. Peserta pelatihan berjumlah 15 orang dari jumlah total undangan 30 orang. Ada beberapa guru yang tidak mengikuti kegiatan pengabdian ini dikarenakan pandemi Covid 19 sehingga dibatasi peserta antara 15 sampai dengan 20 orang .

b. Dilihat dari hasil observasi selama kegiatan berlangsung dari tiap pertemuan menunjukkan respon yang positif dari peserta. Para peserta bersikap responsif dan aktif dalam mengikuti setiap tahapan kegiatan. Jika diamati setiap peserta sangat ingin tahu dan ingin mencoba kegiatan pembuatan media modifikasi Penjas yang disampaikan.

c. Guru dalam merancang media modifikasi berdasarkan K13 dengan materi bervariasi sehingga saling melengkapi, dan begitu pula dalam membuat media dapat saling membantu oleh teman-teman guru.

d. Melihat dari hasil pantauan tim pengabdian, secara keseluruhan para guru telah melakukan tugas yang diberikan dengan cukup baik. Hal ini dilihat dari hasil yang didesain atau yang dibuat oleh masing-masing guru (mitra), sehingga terdapat beberapa guru peserta pelatihan yang membuat lebih dari dua media modifikasi Penjas yang dipersiapkan untuk disimulasikan dalam ujicobakan pemanfaatan media di depan Tim Pengabdi.

e. Pada kegiatan diskusi hal yang masih banyak dijumpai pada beberapa guru adalah kesulitan merancang/mendesain dalam membuat media 
modifikasi Penjas di SD. Sebagian besar para guru kesulitan untuk berfikir kreatif dan memulai membuat media yang sederhana, menarik dan efektif, hal ini karena belum terbiasa merancang dan membuat media penjas dari bahan barang bekas sebab selama ini media yang ada di sekolah masing-masing adalah media yang dibeli langsung di toko olahraga yang sangat mahal dan kurang efektif pemanfaatannya.

f. Peserta terlihat sangat antusias dalam memperhatikan penjelasan yang disampaikan oleh tim pengabdi dengan respon positif dan tidak malu bertanya apabila ada ketidakpahaman dalam penjelesan tim pengabdi.

g. Peserta pelatihan atau para guru menyambut dengan hangat kegiatan pelatihan yang diberikan oleh tim pengabdi sekalipun dalam pandemi Covid 19, hal ini dapat dilihat dengan antusias para guru menerima dan menyelesaikan tugas yang sudah mereka buat dirumah untuk disimulasikan dalam ujicoba pemanfaatan media modifikasi Penjas di lapangan dan menginginkan untuk tatap muka langsung (praktek) tetapi tetap menenerapkan Protokol kesehatan, dan diadakan perbaikan oleh tim pengabdi. Tidak hanya itu, para guru mengharapkan pada tim pengabdian untuk melanjutkan kegiatan pelatihan dan pendampingan pembuatan media modifikasi yang lebih baik.

h. Berdasarkan hasil pengamatan yang dilakukan oleh tim pengabdi, beberapa masalah yang dihadapi oleh guru SD PJOK kecamatan Cina dalam membuat media modifikasi Penjas di SD adalah kurang kreatifnya guru merancang dan memberanikan diri dalam membuat media dari bahan barang bekas yang ada di sekitar yang dapat dimanfaatkan tanpa mengeluarkan uang yang banyak. Namun setelah dilakukan penjelasan oleh tim pengabdi melalui kegiatan workshop atau pelatihan serta dilakukan kegiatan pendampingan pembuatan media sampai simulasi ujicoba pemanfaatan media modifikasi pembelajaran Penjas, peserta menunjukkan hasil yang lebih baik, yakni dilihat dari hasil perolehan bahan/barang bekas jenis dengan materi ajar, Desain media yang dimodifikasi, unsur kefektifan dan menarik, sampai simulasi pemanfaatan media pada saat ujicoba adalah $100 \%$ dari 15 jumlah peserta yang ada.

i. Berdasarkan kriteria keberhasilan bahwa guruguru SD PJOK kecamatan Cina kabupaten Bone yang tergabung pada KKGPJOK, telah dapat merancang dan membuat media modifikasi Penjas SD yang sederhana efesien dan efektif, sehingga dalam kegiatan PKM pengabdian masyarakat ini dapat dikatakan telah berlangsung sesuai dengan rencana dan berhasil dengan baik.

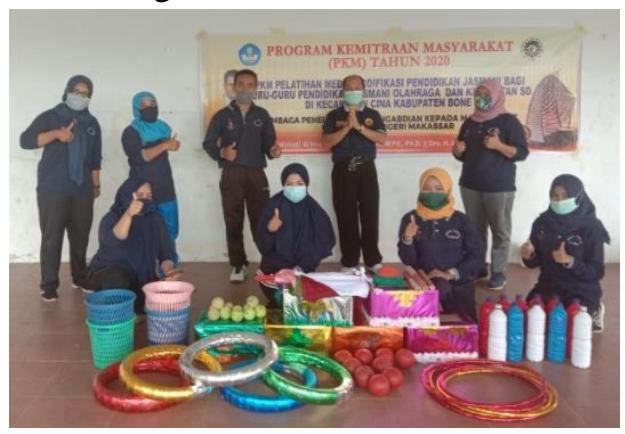

Gambar 10 Hasil Kegiatan Media Modifikasi Penjas di SD (Tatap Muka Langsung menerapkan Protokol Kesehatan dan Izin Pemerintah Setempat)

\section{KESIMPULAN}

Berdasarkan hasil yang dicapai, maka dapat disimpulkan sebagai berikut:

a. Selama mitra mengikuti kegiatan pelatihan pada tiap pertemuan atau tatap muka baik secara virtual, maupun tatap muka langsung dengan tetap mematuhi protokol kesehatan para peserta menunjukkan sikap yang sangat responsif dan aktif dalam mengikuti kegiatan dengan aktif dalam bertanya jawab, serta menyelesaikan tugas yang diberikan oleh tim pengabdi.

b. Media modifikasi pembelajaran Penjas SD bagi guru PJOK sangat penting, untuk meningkatkan kualitas proses dan hasil belajar siswa.

c. Pembuatan media modifikasi Penjas di SD diharapkan sebagai salah satu upaya pengembangan kreativitas dan Inovasi serta sekaligus membantu pemerintah dalam 
mengatasi masalah biaya pengadaan media pembelajaran PJOK di SD pada masa pandemi Corona Covid 19 saat ini.

\section{UCAPAN TERIMA KASIH}

Puji syukur kami panjatkan kehadirat Allah SWT, karena limpahan rahmat, nikmat dan karunia-Nya kami telah selesai melaksanakan kegiatan pengabdian kepada masyarakat pada Kelompok Kerja Guru Pendidikan Jasmani Olahraga dan Kesehatan (PJOK) SD di kecamatan Cina kabupaten Bone, bertempat di Lapangan sepak bola Cina kelurahan Tanete Harapan kecamatan Cina kabupaten Bone. Bentuk pengabdian masyarakat yang telah dilaksanakan adalah PKM Pelatihan Media Modifikasi Penjas bagi Guru-guru PJOK yang bergabung pada KKGPJOK SD kecamatan Cina kabupaten Bone, Alhamdulillah, walaupun dalam masa pandemi Covid 19, kegiatan pengabdian kepada masyarakat ini telah berlangsung dengan baik, tertib, aman, dan lancar sesuai dengan rencana. Oleh karena itu, kami mengucapkan terima kasih yang sebesarbesarnya kepada:

1. Rektor Universitas Negeri Makassar

2. Dekan Fakultas Ilmu Pendidikan

3. Kepala Lembaga Pengabdian kepada Masyarakat

4. Aliamrin, S.Pd dan Syamsuriadi, S. Pd, selaku Ketua dan sekretaris KKGPJOK SD kecamatan Cina

5. Guru-guru PJOK SD di kecamatan Cina kabupaten Bone sebagai Mitra pada kegiatan PKM.

Demikian juga kepada semua pihak terkait yang telah membantu pelaksanaan kegiatan ini yang tidak dapat disebutkan satu persatu, kami mengucapkan terima kasih.

Selanjutnya, kami berharap mudah-mudahan kegiatan pengabdian kepada masyarakat ini bermanfaat bagi para guru-guru PJOK SD kecamatan Cina kabupaten Bone.

Penulis menyadari bahwa selama masa pengabdian dan penyusunan laporan ini masih banyak kekurangan dan kesalahan. Oleh karena itu penulis memohon saran dan kritik dari berbagai pihak yang bersifat membangun sebagai bahan perbaikan di masa yang akan datang. Semoga laporan ini bermanfaat bagi semua pihak.

\section{DAFTAR PUSTAKA}

Bahagia,Yoyo. 2010. Modifikasi Pembelajaran Pendidikan Jasmani, Jakarta: Fasilitas Perlengkapan Penjas Fakultas Pendidikan Olahraga dan Kesehatan Jurusan Pendidikan Olahraga Universitas Negeri Jakarta

Depdiknas. 2006. Panduan Pengembangan Silabus Mata Pelajaran Pendidikan Jasmani. BSNP. Jakarta: Departemen Pendidikan Nasional.

Lutan, R. 2000. Strategi Belajar Mengajar Penjaskes. Depdiknas Dirjen Pendidikan Dasar Dan Menengah Bagian Proyek Penataran Guru SLTP Setara D-III

Saputra, Y.M., 2001. Dasar-Dasar Keterampilan Atletik: Pendekatan Secara Profesional. Jakarta: PT. Elex Media Komputindo Kelompok Gramedia

Soekatamsi dan Srihati Waryati, 1966. Prasarana dan Sarana Olahraga Surakarta: UNS Press

Soepartono. 2000. Media Pembelajaran. Jakarta: Departemen Pendidikan Nasional Direktorat Jenderal Pendidikan Dasar dan Menengah Bagian Proyek Penataran guru SLTP setara DIII.

Subagiyo, dkk. 2005. Perencanaan Pembelajaran Pendidikan Jasmani dan Kesehatan. Jakarta: Universitas Terbuka 